\title{
Technical Note: Mechanical despining of plains pricklypear
}

\author{
D.M. MUELLER AND J.R. FORWOOD
}

\begin{abstract}
Authors are range technician and supervisory range scientist (deceased), respectively, USDA-ARS Central Plains Experimental Range, County Rd. 37, Nunn, Colo. 80648; USDA-ARS Rangeland Resources Research Unit, 1701 Center Avenue, Fort Collins, Colo. 80526.
\end{abstract}

\begin{abstract}
Plains pricklypear cactus (Opuntia polyacantha $\mathrm{L}_{\text {.) }}$ is abundant on the Central Great Plains, producing dry matter yields from 1,500 to $2,000 \mathrm{~kg} / \mathrm{ha}$. Although pricklypear is high in energy and palatable, long sharp spines make it, and vegetation immediately surrounding it, unavailable to livestock. The possibility of simultaneously controlling and feeding plains pricklypear led to development of machinery for harvesting and despining cactus. The mechanical despiner described here adequately removed spines from pads during periods of low relative humidity. Softening of cactus spines due to high relative humidity resulted in failure of the despiner to adequately remove spines. Cattle readily ate despined cactus in the winter when green forage was unavailable.
\end{abstract}

Key Words: cactus, range improvement, Opuntia polyacantha, shortgrass prairie

Over 2,400,000 ha of rangeland in eastern Wyoming and northeastern Colorado have high populations of pricklypear (Opuntia polyacantha L.) (Alley and Lee 1969, Sims 1973). In some instances, pricklypear is a barrier to grazing cattle (Bement 1968, Smith et al. 1985). Several methods for reducing or controlling stand densities have been attempted. Some control methods are blading, beating, burning, or chemical application. These methods are costly and not always effective in killing cactus. They frequently leave cactus pads intact for 2 or more years and may damage or destroy other desirable forage species.

Pricklypear pads are palatable and nutritious (high in energy, low in protein, and phosphorus) once spines have been removed (Shoop et al. 1977). In the past removing the spines by singeing made cactus pads available as feed (Thatcher et al. 1964, Hyde et al. 1965, and Sims 1973). Livestock producers have historically fed pricklypear during droughts (Griffiths 1906, Woodward et al. 1915) and still utilize it as emergency feed. Chemical analysis and digestion trails have shown plains pricklypear digestibility to be equal or superior to that of high quality hay (Shoop et al. 1977). The possibility of simultaneously controlling and collecting plains pricklypear for later feeding to livestock led to development of a cactus harvester (Mueller et al. 1994). The study objective was to develop equipment that removed spines from harvested pricklypear, thereby making pricklypear available as livestock feed.

\section{Materials and Methods}

We designed and constructed a hydraulic powered mechanical despiner to remove spines from pricklypear cactus pads (Fig. 1). Cactus

Manuscript accepted 22 Mar. 1994. pads fed into an opening at one end of the despiner are propelled by rotating chains through 8 connected horizontal cylinders. The scraping action of pads against the rasp-lined walls of the cylinders removes spines while leaving pads intact. Despined pads are then ejected out the opposite end of the despiner.

The despiner consists of eight $76.2-\mathrm{cm}$ long cylinders $38.7-\mathrm{cm}$ inside diameters (ID). Cylinders are made of $0.3-\mathrm{cm}$ steel with $0.6-\mathrm{cm}$ perforations. Each cylinder is lined on the inside with seventeen 3.8$\mathrm{X} 25.4-\mathrm{cm}$ "sure form"' rasps designed for shaping auto body plastic. Individual rasps are attached in grooves on linoleum edging connected to the inside of each cylinder. Cylinders are arranged to allow continuous flow of cactus pads from one to another through adjustable openings (slots) between them (Fig. 2). Slot size between cylinders is controlled with sliding covers made from sections of perforated steel cylinder. Once the desired slot size is obtained the sliding cover is attached to that portion of the cylinder it overlaps with bolts. Cactus pads are propelled through the despiner by rotating $15.2-\mathrm{cm}$ long steel chains attached to four $1.3-\mathrm{cm}$ outside diameter (OD) by $76.2-\mathrm{cm}$ long steel rods. The inside of the chain link is $1.3-\mathrm{cm}$ across so that it will slide over the rod. Spacers made of $1.9-X 2.5-\mathrm{cm}$ P.V.C. pipe separate each chain (Fig. 3). The rods are attached to the comers of three 0.6$X 7.6-X 7.6-\mathrm{cm}$ square plates on a $1.9-\mathrm{X} 83.8-\mathrm{cm}$ shaft through the center of each $38.7-\mathrm{cm}$ ID cylinder (Fig. 3). Each shaft is rotated in the opposite direction of the preceding shaft. Chain lengths are adjusted so that they operate within $1.3-\mathrm{cm}$ of the cylinder wall. Centrifugal force from rotating chains move the pads along the rasplined perforated wall of each cylinder and from cylinder to cylinder. Cactus spines become detached by shearing action of pad against cutting edges of rasps (Fig. 2). Adjustment of slot size and chain speed (rpm) controls the flow rate of cactus pads through cylinders. Chain speed also controls the centrifugal force needed to remove spines from cactus without excessive pad damage.

\section{Drying Study}

Initial testing of the despiner during the design phase seemed to indicate pad moisture may affect spine removal efficiency. Thus, despiner efficiency on freshly harvested pads versus pads harvested and dried for a week were tested in study I. Pricklypear cactus pads were collected with hand rakes on 9 and 23 July 1990 at the Central Plains Experimental Range near Nunn, Colorado. Approximately 300 cactus pads ( 35 liters) were treated by the despiner on the day collected. A second 35 liters of cactus were despined after intact pads were air dried for one week. A random sample of 10 pads taken from each 35 liters of cactus prior to a trial run through the despiner were used to Mention of a trademark or manufacturer by the USDA does not imply its approval to the
exclusion of other productions or manufacturers. 


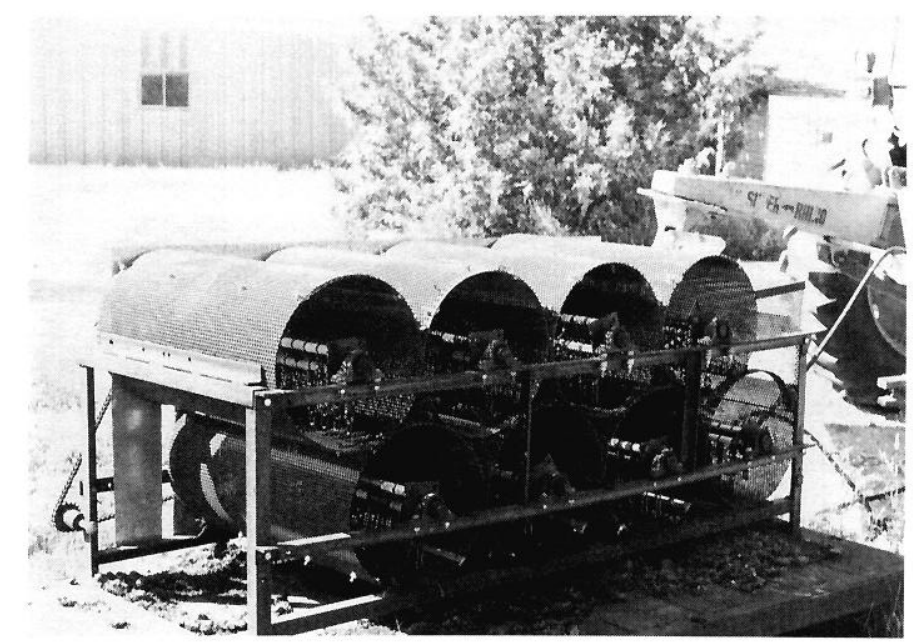

Fig. 1. Cactus despiner developed by USDA-ARS Central Plains Experimental Range.

determine water content of cactus pads. Pads were sliced to facilitate drying then oven dried at $60^{\circ} \mathrm{C}$ for 2 days. Slot size between cylinders and chain rpm were adjusted before each test for removal of maximum number of spines. Adjustments were done by trial and error on both the freshly harvested and air dried samples.

Estimates of spine removal efficiency were based on a subjective rating of good, fair, and poor. A 'good' rating meant that the majority of pads were completely free of spines and glochids with occasional pads having spines that were broken at the base or tip so as to be easily handled without gloves. 'Fair' rating meant that some spines were attached to $50 \%$ or more of pad edges or creases, however the spines had been rendered harmless through breakage. 'Poor' removal of spines meant that most spines and glochids were still intact and attached solidly enough to make handling of the pad without gloves difficult, thus severely reducing palatability to livestock.

\section{Humidity Study}

The drying study results led to a second study which tested the effects of relative humidity $(\mathrm{RH})$ on despiner efficiency. Cactus were collected with hand rakes 7 March 1991. One randomly selected 35liter sample of cactus was placed in a growth chamber set at $21^{\circ} \mathrm{C}$ and $95 \% \mathrm{RH}$ for 5 days and another randomly selected 35 -liter sample was placed in a growth chamber set at $21^{\circ} \mathrm{C}$ and $40 \%$ RH for 5 days. Pad water content was determined by the same methods used in the drying study. The despiner was adjusted for optimum removal of spines under existing pad and environmental conditions. Cactus from the high RH chamber were kept in plastic bags with an open source of water until despined. After despining, spine density (spines/pad) was determined by counting spines on 20 random samples from each of the humidity treatments. This was compared to the number of spines on 20 random samples of cactus not run through the despiner (check). Glochids and short spines at the bases of longer spines were not counted on any of the samples. One-way analysis of variance was performed on the results. Duncan's new multiple range test was used for mean separation $(P \leq 0.05)$.

\section{Feeding Trials}

Treated cactus from the drying study was given to eleven $300-\mathrm{kg}$ steers 2 August 1990 . The steers were placed into 3 pens. Two pens contained 4 steers each with 3 in the other. Each pen had water and two 35-liter containers filled with despined cactus for duration of the study. The study was designed to go a maximum of 6 hours or until all the cactus had been eaten.
Treated cactus from the humidity study was given to twelve $430-\mathrm{kg}$ heifers 8 March 1991. Heifers were given cactus in two 35-liter containers as they watered in the morning. One container was filled with cactus kept at high humidity before despining and the other container had cactus kept at low humidity prior to despining. In both studies all cattle were observed by three individuals and notes were taken whenever an attempt or actual ingestion or mastication of cactus occurred.

\section{Results and Discussion}

\section{Drying Study}

The pricklypear despiner performed poorly on cactus treated the same day collected. The despiner performed best ("fair" removal of spines) on cactus collected 9 July and dried for a week prior to spine removal. Pad water content was 69 and $74 \%$ for cactus collected 9 July and 23 July, respectively. Relative humidity ranged from 80 to $90 \%$ on 9 July and from 60 to $70 \%$ on 23 July. Pad water content after one week drying remained high (71\%), but $\mathrm{RH}$ dropped to 30 to $40 \%$. Our assumption was that decreased $\mathrm{RH}$ increased spine removal efficiency. Previous experience during the design phase suggested that poor spine removal occurred on humid days when it was either foggy or raining.

\section{Humidity Study}

Spine removal from pads kept at low RH (40\%) was significantly better than those pads kept at high $\mathrm{RH}(90 \%)$ and both treatments were significantly better then the control, no despining (Fig. 4).Density (spines/pad) of broken and/or intact spines after despining averaged 14 for cactus kept at low RH and 56 for cactus treated at high RH while pads not despined averaged 93 (Table 1). Very few spines left on the pads after despining were intact, which made it easy to handle the cactus pads from both humidity treatments without gloves. Pads not through the despiner were impossible to handle without gloves (Fig. 4). Pad water content was probably not a factor in spine removal since pads averaged 55 and $58 \%$ for low and high $\mathrm{RH}$ treatments, respectively.

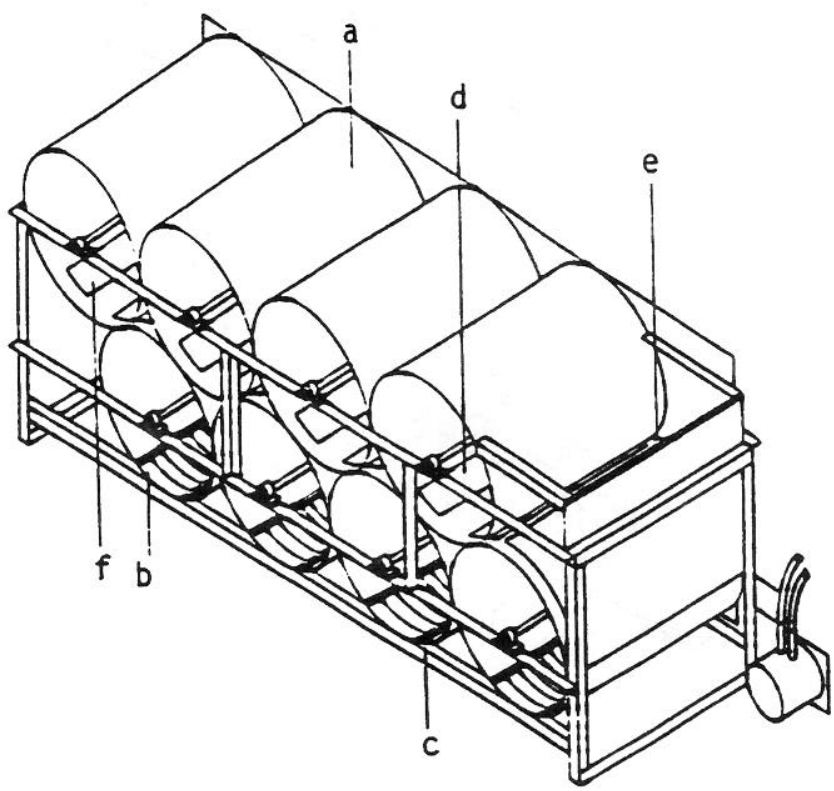

Fig. 2. Side view of pricklypear cactus despiner cylinders. Letters refer to: (a) 38.7 ID- X 76.2-cm long cylinders; (b) 3.8- X 25.4-cm rasps; (c) 2.54 $X$ 76.2-cm linoleum edging; (d) 15.2- X 66.0-cm adjustable slots; (e) cactus entrance; (f) cactus exit. 
Table 1. Number of spines remaining on cactus pads kept at high (95\%) and low $(\mathbf{4 0} \%$ ) relative humidity in growth chamber following mechanical despining compared to control (non despined) pads.

\begin{tabular}{|c|c|c|}
\hline \multirow[b]{2}{*}{ Control } & \multicolumn{2}{|c|}{ Mechanically Despined } \\
\hline & $\begin{array}{c}\text { High } \\
\text { Humidity }\end{array}$ & $\begin{array}{c}\text { Low } \\
\text { Humidity }\end{array}$ \\
\hline \multirow[b]{2}{*}{$93 c^{1}$} & \multicolumn{2}{|c|}{ (Spines) } \\
\hline & $56 \mathrm{~b}$ & $14 \mathrm{a}$ \\
\hline
\end{tabular}

Means with the same letter are not significantly different $(P \leq 0.05)$.

Moisture adsorbed by spines from the air or pad surface of cactus kept at high humidity may have caused either spines or spine bases to soften, allowing them to flatten against the pads instead of becoming caught and removed by the rasps during the despining operation. Pads with high water content (summer 1990) were more susceptible to damage from the despiner than pads with low water content (winter 1991). Moisture released from macerated cactus pads (pads torn into pieces) during the 1990 trials may have contributed, along with high $\mathrm{RH}$, to spine softening. Rasp effectiveness decreased as the holes in rasps became plugged with vegetative matter from damaged cactus pads. Operator control of flow rate and centrifugal force on cactus is important to avoid pad damage.

\section{Feeding Trials}

Cattle would not eat treated cactus offered to them in the summer of 1990, even after a 6 hour fast. Approximately two 35-liter containers of treated cactus were readily eaten by several cattle when placed before them in March, 1991. They ate, without hesitation, all cactus supplied to them from both high and low humidity treatments without prior fasting. Observations during the trials led us to believe the reasons were probably two fold: 1) The despiner removed and/or damaged the tips of more cactus spines in March 1991 than in the summer of 1990 , 2) There was no other green vegetation available to cattle in March 1991, whereas during the summer of 1990 there was other green vegetation available.

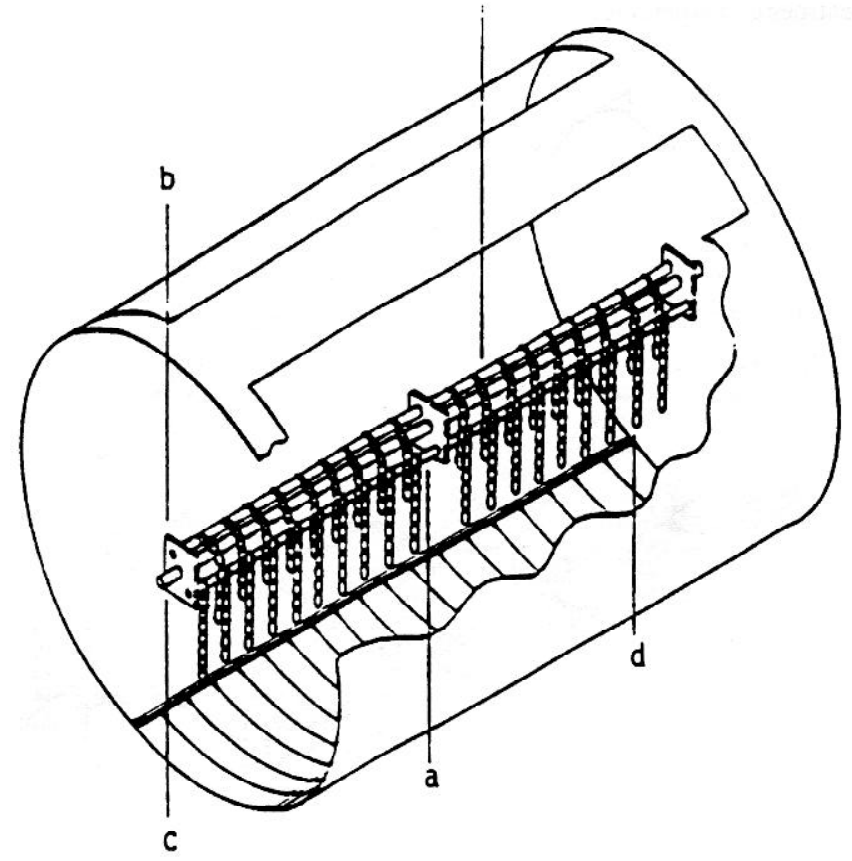

Fig. 3. Expanded view of pricklypear cactus despiner cylinder and rotating chains. Letters refer to the following: (a) $1.3 \mathrm{OD}-\mathrm{X} \mathbf{7 6 . 2}-\mathrm{cm}$ long rod; (b) 0.6- X 7.6- X 7.6-cm plate; (c) 1.9 OD- X 83.8-cm long shaft; (d) 15.2-cm long chain; (e)1.9 ID- X 2.5-cm long P.V.C. pipe spacers.

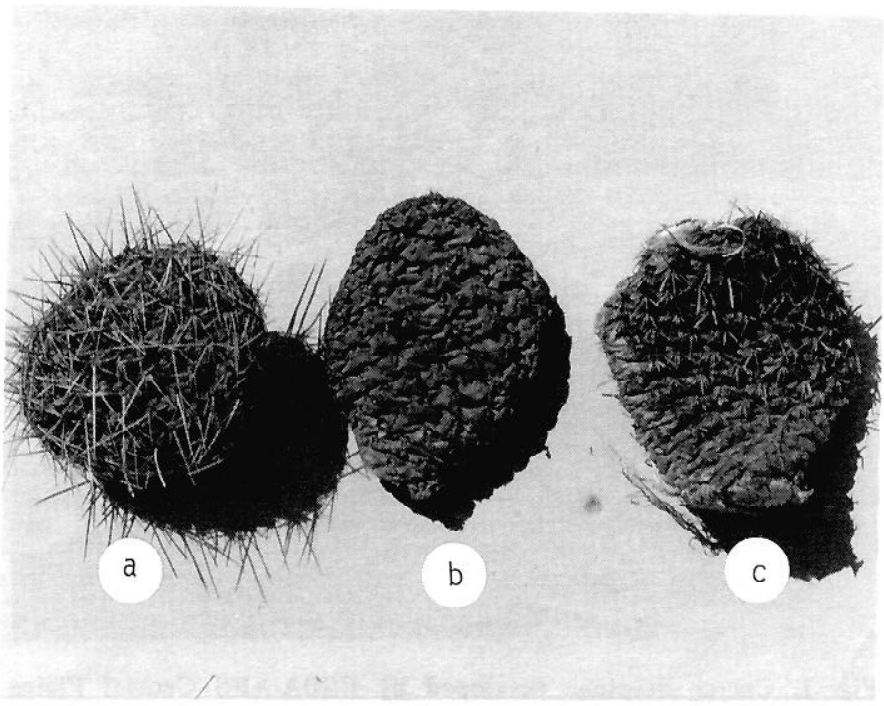

Fig. 4. Cactus pad (a) before spine removal (b) pad kept at low humidity for 5 days prior to despining and (c) compared to cactus pad kept at high humidity for 5 days prior to despining

\section{Conclusion}

Mechanical despining can remove spines from pads during periods of low RH. At high RH cactus spines are softened, resulting in less efficient removal by the despiner. However, tips and base of spines were broken and damaged enough to permit handling without gloves and consumption by cattle. Cattle readily ate despined cactus in the winter when other forage was dry and avoided despined cactus in the summer when more desirable forage was available. The despiner also performed more efficiently in the winter because the pads were drier and less susceptible to damage (torn pads) by the machine.

The despiner, in conjunction with a cactus harvester, could provide a three-fold advantage to producers by controlling pricklypear, making existing forage more available to livestock, and providing an additional livestock feed source during winter or drought periods. Further long term feeding trials should be undertaken and cattle tested for any possible ill effects from eating cactus from the despiner before the machine is marketed commercially. The prototype machine has addressed only function, and not durability or safety. A commercial machine would need structural strengthening and safety standards met.

\section{Literature Cited}

Alley, H.P and G.A. Lee. 1969. Chemical control of plains pricklypear in Wyoming. Wyo. Agr. Exp. Sta., Bull. 497.

Bement, R.E. 1968. Plains pricklypear: relation to grazing intensity and blue grama yield on Central Great Plains. J. Range Manage. 21:83-86.

Griffiths, D. 1906. Feeding prickly pear to stock in Texas. USDA Bur. Animal Ind. Bull. 91.

Griffiths, D. 1912. The prickly pear as a farm crop. USDA Bur. Plant Indus. Bull. 124.

Hyde, R.M., A.D. Hulett, H.P. Alley. 1965. Chemical and mechanical control of plains pricklypear in north-eastern Wyoming. Agr. Ext. Serv., Circ. 185.

Shoop, M.C., E.J. Alford, and H.F. Mayland. 1977. Plains pricklypear is a good forage for cattle. J. Range. Manage. $30 ; 12-17$.

Sims, P.L. 1973. Effect of herbicides on the control of pricklypear cactus in northeastern Colorado. Colo. Agr. Exp. Sta. Prog. Rep. No. 70-72.

Smith, M.A., J.L. Dodd, and J.D. Rodgers. 1985. Prescribed burning on Wyoming rangeland. Agr. Res. Serv. Univ. Wyo. Bull. 810:10-11

Thatcher, A.P., G.V. Davis H.P. Alley. 1964. Chemical control of plains pricklypear in southeastern Wyoming. J. Range. Manage. 17:190-193.

Woodward, T.E. W.F, Turner, and D. Griffiths. 1915. Pricklypear as feed for daily cows. J. Agr. Res. 4:405-450. 